\title{
Control of Culex pipiens (Diptera: Culicidae), the vector of lymphatic filariasis, using irradiated and non-irradiated entomopathogenic nematode, Steinernema scapterisci (Rhabditida: Steinernematidae)
}

\author{
R. M. Sayed*i(D, R. S. Abdalla, S. A. Rizk and T. S. El sayed
}

\begin{abstract}
The goal of this work was to investigate the effect of gamma irradiated entomopathogenic nematode EPN; Steinernema scapterisci on third and fourth larval instars of Culex pipiens under laboratory conditions and its effect on the elemental composition of the treated larvae. Results showed that normal and irradiated tested nematodes differed in their efficacies against third and fourth larval instars. The mortality rates increased with increasing the nematode concentration and the period after treatment, in most cases the mortality in fourth instar larvae was more than in third instar larvae under the same treatments, and the percentage of mortality in irradiated nematodes was more than that in unirradiated ones. Studying the elemental composition showed that phosphorus (P) was the highest concentration in untreated larvae or those treated with normal S. scapterisci, while calcium (Ca) was the highest concentration in gamma irradiated S. scapterisci. The lowest concentration in untreated larvae was zinc (Zn), while copper (Cu) was the lowest concentration in unirradiated and 2 Gy gamma irradiated S. scapterisci. In conclusion, the gamma irradiation of $S$. scapterisci enhanced its efficacy against C. pipiens, therefore it could serve as safe control method for C. pipiens.
\end{abstract}

Keywords: Entomopathogenic nematodes, Gamma radiation, Culex pipiens, Elemental composition

\section{Background}

Culex species are important vectors of human pathogens world-wide. The most important Culex vectors are those members of $C$. pipiens $L$. complex, a very closely related group of species that originated in Africa but has spread by human activity to tropical and temperate climate zones in all continents. More than 100 million people are infected worldwide with the Wuchereria bancrofti form of lymphatic filariasis that is transmitted primarily by $C$. pipiens complex mosquitoes in urban and suburban settings, and approximately 43 million filariasis cases are seriously disabled (UNDP/World Bank/WHO/TDR and WHO/UNICEF 1998).

\footnotetext{
* Correspondence: rehab.omar@yahoo.com

Natural Products Department, National Centre for Radiation Research and

Technology, Atomic Energy Authority, 3 Ahmed ElZomor St., Scientific

Divisions Building-5th floor, P.O. Box 29, Nasr City, Cairo, Egypt
}

Recently, both C. pipiens (Northern house mosquito) and C. quinquefasciatus (Southern house mosquito), together with C. tarsalis and several other Culex species, have attracted much attention within the USA and Canada as significant vectors of West Nile Virus. When one considers the number of human pathogenic viruses that Culex species transmit combined with the numbers of people afflicted with lymphatic filariasis, the overall disease burden created by members of the genus Culex is very large. This burden caused by Culex species exceeds those of dengue and yellow fever transmitted by Aedes aegypti (estimated at $~ 20$ million) (Goddard et al. 2002).

Various biological control agents, such as viruses, bacteria, fungi, and nematodes have been tested in the control of urban pests as an alternative to using conventional 
insecticides with their attendant problems. Recently, the potential of entomopathogenic nematodes (EPNs) has been used for the biological control of insect pests (Trdan et al. 2007 and Laznik et al. 2010).

Welch and Bronskill (1962), Dadd (1971), and Poinar Jr and Kaul (1982) were the first who studied the potentiality of the rhabditoid nematode and its associative bacterium against mosquitoes. Recently, a laboratory colony of the mosquito, C. apicinus was parasitized by the nematode, S. rarum (Cagnolo and Almirón 2010). Furthermore, Ayaba et al. (2012) indicated that the mermithid nematode, Romanomermis iyengari is effective for malaria vector control in Benin, West Africa. In addition, Zohdy et al. (2013) stated that EPNs can be considered effective biocontrol agents of pest insects in aquatic habitat.

Radiation technique serves as a safe and cheap physical control method for pests that can be integrated with other control ways. Regarding the finding of Marples and Collis (2008), low-radiation dose may enhance the activity of the irradiated organism. Moreover, Yussef (2006) studied the effect of gamma irradiation doses $2.5 \mathrm{~Gy}, 5 \mathrm{~Gy}$, and $10 \mathrm{~Gy}$ on the pathogenicity of S. carpocapsae; she found that the lowest were more effective than the higher ones. In addition Sayed (2011), Salem et al. (2014), and Sayed et al. (2015) noticed that the infective juveniles of $S$. carpocapsea were activated by 2 Gy irradiation.

Since the hemolymph is the target site of pathogenicity and the insect possesses a well-developed innate immune system for protection against nematode, which exhibited both as cellular and humoral reactions. So, biochemical alterations in the hemolymph components are occurred (EL-Bishry and Eid 1992). Since El-Sadawy et al. (2009) demonstrated a significant decline in total protein and total lipids and alteration in different amino acids concentration in both Parasarcophaga sarchophaga and Argas persicus post treatment with $H$. bacteriophara and S. riobrave. Furthermore, Ahmed et al. (2014) declared a significant decrease in the principle nutrients (total protein, carbohydrate, and lipid) and the activity of transaminases (GOT and GPT) of Spodoptera littoralis after treatment with $H$. bacteriophora and S. riobrave.

Therefore, the present work aimed to study the possibility of control of $C$. pipiens larvae through the parasitism of irradiated and non-irradiated Steinernema scapterisci and study the changes induced in their mineral contents.

\section{Materials and methods}

\section{Rearing of mosquitoes}

Laboratory reared colony of C. pipiens, kindly supplied by the Faculty of Science, Ain Shams University, Cairo, Egypt, was sustained starting from egg rafts that sieved into large plastic containers with water. The resulting larvae were held in enamel trays with 11 of dechlorinated water with $0.15 \mathrm{~g}$ of Brewer's yeast: lactalbumin (50:50). The water was replaced by fresh water alternate days, whereas food was added daily. Adults were held in $0.51 \mathrm{~m}^{3}$ aluminum screen cages and supplied with $10 \% \mathrm{su}-$ crose solution on cotton wicks. Restrained quail was used to blood-feed insect female. Deposited egg rafts were collected in a 400-ml-plastic container. The colony was maintained at $26{ }^{\circ} \mathrm{C}$ and a relative humidity of $75 \%$ with a $16 \mathrm{~L}: 8 \mathrm{D}$ photoperiod. The third and fourth larval instars were used in the experiments.

\section{The tested nematode}

S. scapterisci was obtained from the Agriculture Research Centre, Giza, Egypt and mass reared on the last instar larvae of the greater wax moth, Galleria mellonella L. according to Bedding and Akhurst (1975). The infective juveniles (IIs) were gamma irradiated by the dose of $2 \mathrm{~Gy}$, using Gamma Cell Irradiation Unit (cesium, $\mathrm{Cs}^{137}$ source) located in the National Centre for Radiation Research and Technology (NCRRT) (Sayed 2011).

The dose rate calibration determined for gamma radiation at the time of the experiment was $0.688 \mathrm{rad} / \mathrm{s}$. Virulence of irradiated $S$. scapterisci to third and fourth larval instars of $C$. pipiens: third and fourth larval instars were exposed to serial concentrations of $S$. scapterisci in a bioassay technique according to Woodering and Kaya (1988). Five larvae were placed in $100 \mathrm{~cm}^{3}$ plastic cups filled with $10 \mathrm{ml}$ distilled water containing the nematodes $(50 \mathrm{IJs} / 10 \mathrm{ml}$, $100 \mathrm{IJs} / 10 \mathrm{ml}, 200 \mathrm{IJs} / 10 \mathrm{ml}$, and $400 \mathrm{IJs} / 10 \mathrm{ml})$. Three replicates were conducted for each concentration and for the control. The control was filled by only distilled water. Experiments were held in the laboratory under $25{ }^{\circ} \mathrm{C} \pm 2{ }^{\circ} \mathrm{C}$. Larval mortalities were recorded daily, and the accumulative percent mortality was also calculated. Percentages of mortalities were corrected according to Abbott's formula (Abbott 1925). Values of $\mathrm{LC}_{50}$, using a software package Ldp-line" a copyright by Ehab, M. Bakr, Plant Protection Research Institute, ARC, Giza, Egypt. The toxicity index (Ti) was calculated using the equation of Sun (1950) as follows: $\mathrm{Ti}=\mathrm{LC}_{50}$ of $\mathrm{A} / \mathrm{LC}_{50}$ of $\mathrm{B} \times 100$.

Where $A$ is the most effective material, and $B$ the other tested material.

About $50 \mu \mathrm{m}$ of $C$. pipiens larvae treated with normal and 2 Gy gamma irradiated S. scapterisci, were dried grounded and analyzed by Energy Dispersive X-ray analyzer (EDX); this analyzer was attached to scanning electron microscope model HEOL-JSM 4500. The program software used is OXFORED-ISIS under windows.

The constituent of the EDX unites:

1. X-ray detector.

2. Multichannel analyzer. 
3. A programmed computer with X-ray analysis software. X-ray was emitted from the samples surface when bombarded with an electron beam. By these analysis the kinds of elements exist in the adults' body and the percentage of each metal were determined.

\section{Statistical analysis}

The data were statistically evaluated by analysis of variance (F) followed by Duncan's multiple range test to examine the significant differences between treatments. The 5\% level of probability was used in all statistical tests. The statistical software program CoStat (1995) was used for all analyses.

\section{Results and discussion}

Results of the concentration-mortality response experiments were showed in Tables 1 and 2. As shown in Table 1, normal and irradiated tested EPN differed clearly in their effects against third instar larvae, where the mortality rates increased with increasing the nematode concentration. In addition, the results revealed that irradiated nematode was more effective than non-irradiated one.

Data in Table 2 showed the percentage mortality of the fourth instar C. pipiens larvae infected with non-irradiated and irradiated S. scapterisci. The percentage mortality increased by increasing the used concentration and the time after treatment with nematode and irradiated nematodes were more efficient than normal ones the least percent mortality was $6.667 \%$ when used concentration 50 and 100 (IJs/10 ml) at $24 \mathrm{~h}$ and the highest percent mortality was $73.33 \%$ when used concentration was 400 (IJs/10mml) at $72 \mathrm{~h}$ compared to zero in non-treated larvae.

From the Tables 1 and 2, It was noticed that the highest percent mortality was 60 and $73.33 \%$ for third and fourth larval instars, respectively, when using non-irradiated S. scapterisciat at the concentration 400 (IJ/10 ml) compared to $66.67 \%$ and $100 \%$ for 2 Gy gamma irradiated S. scapterisci.

The $\mathrm{LC}_{50}$ of non-irradiated and irradiated S. scapterisci of the third and fourth larval instars after $48 \mathrm{~h}$ treatment was presented in Table 3. Results were arranged in

Table 1 Accumulative percentage mortality of the third instar Culex pipiens larvae infected by non-irradiated and irradiated Steinernema scapterisci

\begin{tabular}{|c|c|c|c|c|c|c|}
\hline \multirow[b]{2}{*}{ Time exposure } & \multicolumn{3}{|c|}{ S. scapterisci } & \multicolumn{3}{|c|}{ Irradiated S. scapterisci } \\
\hline & $24 \mathrm{~h}$ & $48 \mathrm{~h}$ & $72 \mathrm{~h}$ & $24 \mathrm{~h}$ & $48 \mathrm{~h}$ & $72 \mathrm{~h}$ \\
\hline \multicolumn{7}{|l|}{ Conc. (IJs/10 ml) } \\
\hline Control & 0 & & & & & \\
\hline 50 & 6.667 & 6.667 & 6.667 & 6.667 & 13.33 & 13.33 \\
\hline 100 & 6.667 & 13.33 & 20 & 13.33 & 26.667 & 33.333 \\
\hline 200 & 13.33 & 33.33 & 46.667 & 20 & 53.333 & 60 \\
\hline 400 & 26.667 & 46.667 & 60 & 26.667 & 60 & 66.667 \\
\hline
\end{tabular}

Table 2 Accumulative percentage mortality of the fourth instar Culex pipiens larvae infected by non-irradiated and irradiated Steinernema scapterisci

\begin{tabular}{|c|c|c|c|c|c|c|}
\hline \multirow[b]{2}{*}{ Time exposure } & \multicolumn{3}{|c|}{ S. scapterisci } & \multicolumn{3}{|c|}{ Irradiated S. scapterisci } \\
\hline & $24 \mathrm{~h}$ & $48 \mathrm{~h}$ & $72 \mathrm{~h}$ & $24 \mathrm{~h}$ & $48 \mathrm{~h}$ & $72 \mathrm{~h}$ \\
\hline \multicolumn{7}{|l|}{ Conc. (IJs/10 ml) } \\
\hline Control & 0 & & & & & \\
\hline 50 & 6.667 & 13.33 & 20 & 6.667 & 20 & 33.333 \\
\hline 100 & 6.667 & 20 & 33.333 & 26.667 & 40 & 53.333 \\
\hline 200 & 20 & 33.33 & 53.333 & 40 & 66.667 & 80 \\
\hline 400 & 33.333 & 60 & 73.333 & 46.667 & 86.667 & 100 \\
\hline
\end{tabular}

descending order according to their toxicity to the fourth instar larvae, treated with irradiated S. scapterisci ( $\left.\mathrm{LC}_{50} 126 \mathrm{IJs}\right)$ followed by third instar larvae treated with irradiated S. scapterisci ( $\left.\mathrm{LC}_{50} 233 \mathrm{IJs}\right)$ followed by fourth instar larvae treated with $S$. scapterisci $\left(\mathrm{LC}_{50} 316.9 \mathrm{IJs}\right)$ and finally those of third instar larvae treated with $S$. scapterisci $\left(\mathrm{LC}_{50} 423 \mathrm{IJs}\right.$ ).

It was noticed that fourth instar larvae was more susceptible to the nematode infection than the third instar larvae. This may be due to the difference in the size which affects the penetration of the IJs into the insect body (Bedding et al. 1983).

The present data denoted an increase in the effect of gamma irradiated S. scapterisci that killed larvae faster than normal S. scapterisci. This result agrees with the findings of Yussef (2006) who stated that $S$. carpocapsae irradiated with lower dose (2.5, 5 and 10 Gy) was more effective against Callosobruchus maculatus. Salem et al. (2014) concluded that gamma irradiated (2Gy) S. carpocapsae may attribute as a major control method of $G$. mellonella. Sayed and Shairra (2017) and Sayed et al. (2018) stated that 2Gy irradiated S. carpocapsae was more pathogenic than non-irradiated one against $S$. littoralis larvae. In addition, Sayed et al. (2018) suggested that 2 Gy irradiated $S$. scapterisci can serve as a bio-control method for controlling $B$. zonata. That increase in the

Table $3 L_{50}$ after $48 \mathrm{~h}$ treatment with non-irradiated and irradiated Steinernema scapterisci

\begin{tabular}{llll}
\hline Treatments & $L_{50}$ & Index & RR \\
\hline $\begin{array}{l}\text { Fourth instar larvae treated with } \\
\text { irradiated S. scapterisci }\end{array}$ & $126(108.5-145.6)$ & 100 & 1 \\
$\begin{array}{l}\text { Third instar larvae treated with } \\
\text { irradiated S. scapterisci }\end{array}$ & $233(190.9-301.3)$ & 54.1 & 1.84 \\
$\begin{array}{l}\text { Fourth instar larvae treated with } \\
\text { normal S. scapterisci }\end{array}$ & $316.9(251.1-444.3)$ & 39.7 & 2.51 \\
$\begin{array}{l}\text { Third instar larvae treated with } \\
\text { normal S. scapterisci }\end{array}$ & $423(325.8-634.8)$ & 29.8 & 3.35 \\
$\begin{array}{l}\text { Index and resistance ratio (RR) compared to fourth instar larvae treated with } \\
\text { irradiated S. scapterisci }\end{array}$ & &
\end{tabular}


pathogenicity may regard to that low doses of gamma radiation activate the symbiotic bacteria to multiply more which increase their toxins.

Data presented in Tables 4 and 5 revealed the relative percentage and the arrangement of elemental composition in the whole body tissue of fourth instar larvae of C. pipiens treated with $\mathrm{LC}_{50}$ of normal and 2 Gy gamma irradiated S. scapterisci, as compared to the existence of eight elements in the whole body tissue of untreated $C$. pipiens larvae.

Phosphorus (P) was the most abundant element in untreated and in treated C. pipiens larvae with normal $S$. scapterisci (Table 4). Being (25.58\%) in untreated larvae and decreased to (22.35 and 20.27\%) for C. pipiens larvae treated with normal and 2 Gy gamma irradiated $S$. scapterisci, respectively. Also, statistical analysis showed a highly significant difference in phosphorus concentration between all treatments. The least abundant elements were copper and zinc, with a significant decrease in copper and a highly significant increase in zink between all treatments (Table 4), being (4.64\% and 4.60\%) in control, respectively and became (2.58 and $5.84 \%)$ in C. pipiens larvae infected with normal nematodes or (2.27 and 7.88\%) in C. pipiens larvae infected with 2 Gy gamma irradiated S. scapterisci. Potassium (K) was the second element in untreated control being (16.95\%) and presented a highly significant decline after treatment with normal and 2 Gy gamma irradiated S. scapterisci, (14.38\% and $14.09 \%)$ for C. pipiens larvae infected with normal and 2 Gy gamma irradiated S. scapterisci, respectively. Sulfur (S) represented (12.05\%) in untreated control and significantly increased in larvae infected with $S$. scapterisci to be (13.87\%). Whereas, a significant decrease was reported in larvae treated with 2 Gy irradiated nematode that being $(10.09 \%)$.
The percentage of chlorine and calcium increased in larvae treated with normal nematodes or those treated with irradiated nematodes compared with the untreated control to be $(13.81 \%$ and $15.83 \%)$ in untreated control and $(14.17 \%$ and $19.02 \%)$ and $(14.45 \%$ and $22.68 \%)$ in $C$. pipiens larvae infected with normal and 2 Gy gamma irradiated $S$. scapterisci, respectively. Insignificant difference was found between treatments in case of chlorine but highly significant difference was found between all treatments in case of calcium.

Magnesium (Mg) represented a highly significant difference elevation among all treatments reporting (6.55\%) in the untreated control and increased to (7.79 and $8.27 \%$ ) in larvae infected with normal and irradiated $S$. scapterisci, respectively.

Limited review on the element contents of Culex, all stated that some of the very important minerals such as $\mathrm{Na}, \mathrm{P}, \mathrm{K}, \mathrm{Fe}, \mathrm{Mg}, \mathrm{Mn}, \mathrm{I}, \mathrm{S}, \mathrm{Si}, \mathrm{Se}, \mathrm{Zn}, \mathrm{Ca}, \mathrm{Cl}, \mathrm{Co}, \mathrm{Cu}, \mathrm{Cr}$, $\mathrm{Al}, \mathrm{Mo}, \mathrm{B}, \mathrm{Ge}, \mathrm{As}$, and $\mathrm{V}$ were available in Culex larvae and pupae, which may help for proper physiological processes of aquatic animals after consumption of larvae and pupae (Habib et al. 2005).

The present study indicated that $\mathrm{P}$ and $\mathrm{Ca}$ were the major elements in untreated C. pipiens larvae or those treated with unirradiated or irradiated nematodes, whereas $\mathrm{P}$ is being a component of nucleic acids and phospholipids in membranes, and also important in energy transfer reactions (Chapman 1988).

Regarding the elemental composition of the different treatments, it appeared that some of the elemental concentrations $\mathrm{P}, \mathrm{Ca}$, and $\mathrm{K}$ values were the highest (Table 5). These high values would depolarize vertebrate or crustacean nerve fiber and stop conduction. However, insects' nerves may have different properties with regard to $\mathrm{K}$ and $\mathrm{P}$, or these may be bound in some ways

Table 4 Relative percentage of element composition in the whole body tissue of Culex pipiens larvae treated with normal and 2 Gy gamma irradiated Steinernema scapterisci

\begin{tabular}{|c|c|c|c|c|c|}
\hline \multirow[t]{2}{*}{ Element } & \multicolumn{3}{|l|}{ Treatments } & \multirow[t]{2}{*}{ LSD } & \multirow[t]{2}{*}{$P$} \\
\hline & Control & $\begin{array}{l}\text { Normal } \\
\text { S. scapterisci }\end{array}$ & $\begin{array}{l}2 \text { Gy irradiated } \\
\text { S. scapterisci }\end{array}$ & & \\
\hline Magnesium (Mg) & $6.55 \pm 0.31^{b}$ & $7.79 \pm 0.19^{a}$ & $8.27 \pm 0.38^{a}$ & 1.054 & * \\
\hline Phosphorus (P) & $25.58 \pm 0.53^{\mathrm{a}}$ & $22.35 \pm 0.38^{b}$ & $20.27 \pm 0.36^{c}$ & 1.508 & $* * *$ \\
\hline Sulpfur (S) & $12.05 \pm 0.50^{b}$ & $13.87 \pm 0.09^{\mathrm{a}}$ & $10.09 \pm 0.46^{c}$ & 1.384 & $* *$ \\
\hline Chlorine $(\mathrm{Cl})$ & $13.81 \pm 0.43^{\mathrm{a}}$ & $14.17 \pm 0.53^{\mathrm{a}}$ & $14.45 \pm 0.30^{\mathrm{a}}$ & 1.507 & ns \\
\hline Potassium (K) & $16.95 \pm 0.42^{\mathrm{a}}$ & $14.38 \pm 0.35^{b}$ & $14.09 \pm 0.68^{b}$ & 1.762 & * \\
\hline Calcium (Ca) & $15.83 \pm 0.04^{c}$ & $19.02 \pm 0.56^{\mathrm{b}}$ & $22.68 \pm 0.27^{\mathrm{a}}$ & 1.256 & $* * *$ \\
\hline Copper (Cu) & $4.64 \pm 0.15^{\mathrm{a}}$ & $2.58 \pm 0.43^{b @}$ & $2.27 \pm 0.36^{b}$ & 1.179 & $* *$ \\
\hline Zinc (Zn) & $4.60 \pm 0.23^{c}$ & $5.84 \pm 0.20^{b}$ & $7.88 \pm 0.19^{a}$ & 0.735 & $* * *$ \\
\hline H.M (Cu, Zn) & 9.24 & 8.42 & 10.15 & & \\
\hline
\end{tabular}

$\varrho^{\varrho}=<2$ sigma

$* *^{* * * * *}$ Significant at $\mathrm{p}<0.05$ (one- way ANOVA)

$\mathrm{a}, \mathrm{b}, \mathrm{c}$ Indicate the variance between the means (Duncan's multiple range test) 
Table 5 Arrangement of the elements according to their concentrations in the whole body tissue of C. pipiens larvae treated with normal and 2 Gy gamma irradiated S. scapterisci

\begin{tabular}{llll}
\hline $\begin{array}{l}\text { Arrangement of } \\
\text { the element }\end{array}$ & \multicolumn{2}{l}{ Treatments } \\
\cline { 2 - 3 } & Control & $\begin{array}{l}\text { Normal } \\
\text { S. scapterisci }\end{array}$ & $\begin{array}{l}\text { 2 Gy irradiated } \\
\text { S. scapterisci }\end{array}$ \\
\hline 1 & $\mathrm{P}$ & $\mathrm{P}$ & $\mathrm{Ca}$ \\
2 & $\mathrm{~K}$ & $\mathrm{Ca}$ & $\mathrm{P}$ \\
3 & $\mathrm{Ca}$ & $\mathrm{K}$ & $\mathrm{Cl}$ \\
4 & $\mathrm{Cl}$ & $\mathrm{Cl}$ & $\mathrm{K}$ \\
5 & $\mathrm{~S}$ & $\mathrm{~S}$ & $\mathrm{~S}$ \\
6 & $\mathrm{Mg}$ & $\mathrm{Mg}$ & $\mathrm{Mg}$ \\
7 & $\mathrm{Cu}$ & $\mathrm{Zn}$ & $\mathrm{Zn}$ \\
8 & $\mathrm{Zn}$ & $\mathrm{Cu}$ & $\mathrm{Cu}$ \\
\hline
\end{tabular}

to the organic constituents of the blood. Alternatively, the fibers may be protected from the comparatively high blood of $\mathrm{K}$ and $\mathrm{P}$ by a sheath capable of ionic regulation providing the axons with a local environment containing a lower $\mathrm{K}$ or $\mathrm{P}$ concentrations than those of the blood (Chapman 1988). This may indicate that insects have highly developed powers of regulatory the ionic composition of the blood. The major and trace elements were generally essential to the insect diets, and they have been shown to be extremely important in maintain an ionic balance suitable to the activity of insect cells; as cofactors of some enzyme systems as integral parts of others (Chapman 1988). The change in the elements' concentrations due to S. scapterisci treatments may owe to their effect on the biochemical system of the insect. Wherever, Sayed (2011) found out alterations in the protein, total lipid, and total carbohydrate in G. mellonella larvae treated with both irradiated and non-irradiated S. carpocapsae. Moreover, Sayed et al. (2015) declared that 2 Gy irradiated S. carpocapsae disrupted the antioxidant contents of S. littoralis larvae that led to larval death faster than normal $S$. carpocapsae. Also, Sayed and Shairra (2017) reported changes in phenoloxidase activity, lysozyme activity, and LDH activity of S. littoralis larvae treated with irradiated and non-irradiated S. scapterisci.

Moreover, the increase in some elements' concentration may regard to those present in the infective juveniles invaded in the larvae. Meligy (2018) reported 10 element contents of seven nematode isolates were determined with insignificant differences in concentrations of aluminum $(\mathrm{Al})$, chromium $(\mathrm{Cr})$, and lead $(\mathrm{Pb})$ among all the studied nematode isolates, while significant differences of cadmium $(\mathrm{Cd})$, selenium $(\mathrm{Se})$, zinc $(\mathrm{Zn})$, and manganese $(\mathrm{Mn})$ concentrations among isolates were found. All isolates related to family Heterorhabditidae contained significantly higher copper $(\mathrm{Cu})$, iron $(\mathrm{Fe})$, and cobalt (Co) concentrations than isolates related to family Steinernematidae of EPNs.

\section{Conclusions}

The above findings showed that $S$. scapterisci treatment caused $C$. pipiens larval mortality through disturbance in its elements' concentration which was more obvious at 2 Gy gamma irradiated S. scapterisci treatment. Therefore, 2 Gy gamma irradiated $S$. scapterisci could be a superb eco-friendly method for controlling $C$. pipiens.

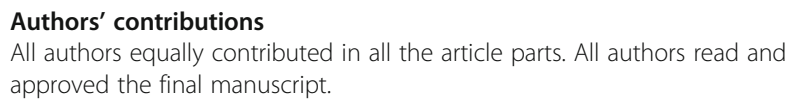

Ethics approval and consent to participate

Not applicable for this section.

Consent for publication

Not applicable for this section.

Competing interests

The authors declare that they have no competing interests.

\section{Publisher's Note}

Springer Nature remains neutral with regard to jurisdictional claims in published maps and institutional affiliations.

Received: 15 May 2018 Accepted: 23 July 2018

Published online: 10 August 2018

\section{References}

Abbott WS (1925) A method of computing the effectiveness of an insecticide. J Econom Entomol 18:265-267

Ahmed NF, Maklad AMH, Yassin SA, Abolmaaty Sh M (2014) Biochemical effects of Steinernema feltiae, Steinernema riobrave and Heterorhabditis bacteriophora on Spodoptera littoralis larvae. EAJBS C Physiology \& Molecular Biology 6(1):23-34 Ayaba ZA, Thierv BCA, Edward GP (2012) Efficacy of the insect parasitic nematode, Romanomermis iyengari, for malaria vector control in Benin West Africa. Malar J 11(1):5

Bedding RA, Akhurst RJ (1975) Simple technique for the detection of insect parasitic rhabditid nematodes in soil. Nenlatologica 21:109-110

Bedding RA, Molyneux AS, Akhurst RJ (1983) Heterorhabditis spp.; Neoaplectana spp. and Steinernema kraussei: interspecific and intraspecific differences in infectivity for insects. Exp Parasitol 55:249-257

Cagnolo SR, Almirón WR (2010) Capacity of the terrestrial entomopathogenic nematode Steinernema rarum (Rhabditida: Steinernematidae) to parasite Culex apicinus larvae (Diptera: Culicidae). Rev Soc Entomol Argent 69:141-145

Chapman RF (1988) Insect structure and function. American Elsevier publishing Co., New York, p 819

CoStat (1995) CoStat, user's manual. Co Hort Software, Minneapolis

Dadd RH (1971) Size limitations on the infectibility of mosquito larvae by nematodes during filter-feeding. J Invert Pathol 18:246-251 https://doi.org/10.1016/00222011(71)90152-2

EL-Bishry MH, Eid MH (1992) Studies on the mode of action of the entomopathogenic nematode Steinernema carpocapsae. III effect of infection of hemolymph protein and esterase activity. Egypt J Appl Sci 7(11):408-417

El-Sadawy HA, Abou-Nour AA, Sobh HA, Ghally SE (2009) Biochemical changes in Parasarcophaga aegyptiaca and Argas persicus (persicargas) haemolymph infected with entomopathogenic nematode. Nat Sci 7(6):70-81

Goddard LB, Roth AE, Reisen WK, Scott TW (2002) Vector competence of California mosquitoes for West Nile virus. Emerg Infect Diseases 8(12):1385-1391

Habib MAB, Yusoff FM, Phang SM, Mohamed S (2005) Experimental production and chemical composition of Culex mosquito larvae and pupae grown in agro-industrial effluent. Asian Fish Sci 18:107-119 
Laznik Ž, Tóth T, Lakatos T, Vidrih M, Trdan S (2010) Control of the Colorado potato beetle (Leptinotarsa decemlineata [Say]) on potato under field conditions: a comparison of the efficacy of foliar application of two strains of Steinernema feltiae (Filipjev) and spraying with thiametoxam. J Plant Dis Protect 117(3):129-135

Marples B, Collis SJ (2008) Low-dose hyper-radiosensitivity: past, present and future. Int J Ratite Oncol Biol Phys 70:1310-1318

Meligy AMA (2018) Comparative study of element contents in seven isolates of entomopathogenic nematodes. Egypt J Biol Pest Control 28:1-7

Poinar GO Jr, Kaul HN (1982) Parasitism of the mosquito Culex pipiens by the nematode Heterorhabditis bacteriophora. J Invert Pathol 39:382-387 https://doi.org/10.1016/0022-2011(82)90063-5

Salem HM, Hussein MA, Hafez SE, Hussein MA, Sayed RM (2014) Ultrastructure changes in the haemocytes of Galleria mellonella larvae treated with gamma irradiated Steinernema carpocapsae BA2. J Rad Res Appl Sci 7(1):74-79

Sayed RM (2011) Combined effect of gamma radiation and an entomopathogenic nematode on some stored product pests, Ph.D. thesis. Faculty of Science, Ain Shams University, P. 125 http://www.iaea.org/inis/ collection/NCLCollectionStore/_Public/45/099/45099886.pdf

Sayed RM, Khidr AA, Moustafa HZ (2015) Changes in defense mechanism related to controlling Spodoptera littoralis larvae by gamma irradiated Steinernema carpocapsae BA2. J Entomol Res 39(4):287-292

Sayed RM, Shairra SA (2017) Enhancing the efficacy of entomopathogenic nematodes by gamma radiation in controlling Spodoptera littoralis larvae. J Rad Res Appl Sci 10:97-102

Sayed RM, Zahran NF, Hamza AF (2018) Evaluation of the synergistic effect of gamma irradiated Steinernema scapterisci and soil depth in controlling Bactrocera zonata Saunders (Diptera: Tephritidae). J Rad Res Appl Sci 11(1):18-22

Sun YP (1950) Toxicity index on improved method of comparing the relative toxicity of insecticides. J Econ Entomol 43:45-53

Trdan S, Žnidaračič D, Vidrih M (2007) Control of Frankliniella occidentalis on greenhouse-grown cucumbers: an efficacy comparison of foliar application of Steinernema feltiae and spraying with abamectin. Russ I Nematol 15(1):25-34

UNDP/World Bank/WHO Special Programme for Research and Training in Tropical Diseases, WHO/UNICEF Joint Programme for Health Mapping \& World Health Organization. Division of Tropical Diseases (1998) Research on rapid geographical assessment of Bancroftian filariasis. World Health Organization, Geneva http://www.who.int/iris/handle/10665/63960

Welch HE, Bronskill JF (1962) Parasitism of mosquito larvae by the nematode DD136 (Nematoda: Neoaplictanidae). Can J Zool 40:1200-1208

Woodering JL, Kaya HK (1988) Steinernematid and heterorhabditid nematodes: a handbook of techniques. Arkansas Agricultural Experiment Station, p 30

Yussef DM (2006) Biological and biochemical studies on the effect of parasitic nematodes, some plant extracts and gamma radiation on Callosobruchus maculates (F), M.Sc. Thesis. Fac. Girls, Ain Shams University, Egypt, p 136

Zohdy NM, Shamseldean MM, Abd-El-Samie EM, Hamama HM (2013) Efficacy of the steinernematid and heterorhabditid nematodes for controlling the mosquito, Culex quinquefasciatus Say (Diptera: Culicidae). J Mosq Res 3:33-44

\section{Submit your manuscript to a SpringerOpen ${ }^{\circ}$ journal and benefit from:}

- Convenient online submission

- Rigorous peer review

- Open access: articles freely available online

- High visibility within the field

- Retaining the copyright to your article

Submit your next manuscript at $\boldsymbol{\nabla}$ springeropen.com 